\title{
Therapeutic potential of alpha-1 antitrypsin in human disease
}

\author{
Minsun Kim, MD, $\mathrm{PhD}^{1,2}$, \\ Qing Cai, MD, PhD ${ }^{3}$, \\ Youngman $\mathrm{Oh}, \mathrm{PhD}^{3}$
}

${ }^{1}$ Department of Pediatrics, Chonbuk National University Medical School, Jeonju, ${ }^{2}$ Research Institute of Clinical Medicine of Chonbuk National University-Biomedical Research Institute of Chonbuk National University Hospital, Jeonju, Korea, ${ }^{3}$ Department of Pathology, School of Medicine Medical College of Virginia Campus, Virginia Commonwealth University, Richmond, VA, USA

\begin{abstract}
Alpha-1 antitrypsin (AAT), an alpha globulin glycoprotein, is a member of the serine protease inhibitor (serpin) superfamily. The clinical significance of AAT is highlighted by AAT deficiency. Genetic deficiency of AAT can present as several neutrophilic diseases associated with emphysema, liver cirrhosis, panniculitis, and systemic vasculitis. Recently, animal and human studies have shown that AAT can control inflammatory, immunological, and tissue-protective responses. In addition, AAT treatment can prevent overt hyperglycemia, increase insulin secretion, and reduce cytokine-mediated apoptosis of pancreatic $\beta$-cells in diabetes. These multifunctional roles of AAT draw attention to the glycoprotein's therapeutic potential for many inflammatory and autoimmune diseases beyond AAT deficiency. As underlying mechanisms, recent studies have suggested the importance of serine protease inhibitory activity of AAT in obesity-associated insulin resistance, chronic obstructive pulmonary disease, and cystic fibrosis. In this review, we explore the multiple functions of AAT, in particular, the anti-inflammatory and serine protease inhibitory functions, and AAT's therapeutic potential in a variety of human diseases through published literature.
\end{abstract}

Keywords: Alpha 1-antitrypsin, Therapeutic uses, Chronic obstructive pulmonary disease, Diabetes mellitus

\section{Introduction}

Alpha-1 antitrypsin (AAT), a $52-\mathrm{kDa}$ serine protease inhibitor, is synthesized in the liver by hepatocytes and circulates in the bloodstream; it is also synthesized, to a lesser extent, by macrophages/monocyte, pancreas, lung alveolar cells, enterocytes, the endothelium, and some cancer cells. ${ }^{1)}$ Recently, many studies have reported that AAT plays important multifunctional roles as an anti-inflammatory, immunomodulatory, anti-infection, and tissue repair-related molecule ${ }^{2-4)}$ that protects tissues from damage induced by enzymes released from cells. ${ }^{5}$

Recent studies have further demonstrated the safety and efficacy of AAT administration not only as a replacement therapy for AAT deficiency, but also as a potential therapy for many other human diseases. In addition, a few studies have assessed the therapeutic utility of alternative AAT sources, including transgenic and recombinant sources, as well as their diagnostic value.

\section{Overview of AAT therapy}

\section{AAT deficiency}

AAT deficiency is an autosomal codominant hereditary disorder that causes defective AAT production, which leads to decreased AAT activity in both the blood and lungs as well as the accumulation of excessive, non-functional AAT protein in liver cells. ${ }^{6,7}$ It is often subject

https://orcid.org/0000-0002-73242073 
to delayed diagnosis because (1) Asymptomatic AAT level reductions, as low as $85 \%$ of normal circulation levels in healthy individuals, can be easily detected in random assessments ${ }^{8}$; (2) Biochemical analyses, such as western blotting and enzymelinked immunosorbent assays, can misinterpret the inactivated form of AAT as the functional form ${ }^{9}$; and (3) Relative functional deficiency can exist as shown through the failure of AAT under physiological conditions. ${ }^{10)}$ AAT deficiency affects $1 / 4,000-1 / 5,000$ people and $1 \%-2 \%$ of all chronic obstructive pulmonary disease (COPD) patients in the United States. ${ }^{11)}$ The main clinical conditions associated with AAT deficiency include COPD and liver cirrhosis. Nevertheless, it has broad spectrum pulmonary and extrapulmonary manifestations leading to pulmonary emphysema or COPD in adults as well as various liver diseases, panniculitis, pancreatitis, glomerulonephritis, and vascular diseases in a minority of children and adults. It is occasionally associated with less common problems such as fibromyalgia, mood disorders, and intense creative energy ${ }^{12-15)}$ The development of COPD is related to a decrease in the function or levels of AAT in the serum, which renders neutrophil elastase (NE) free to break down elastin and causes decreased elastin levels. The detected normal range of AAT in the serum varies because of variability in commercial standards. Based on the onset of emphysema, an abnormal AAT value is 11 $\mu \mathrm{M}$ or lower. ${ }^{16-18)}$

The only safe treatment available for emphysema due to AAT deficiency is intravenous AAT augmentation. However, the efficacy of this treatment remains controversial. Because the incidence is usually low and disease progression is slow, it is impractical to conduct appropriate studies to evaluate the rate of lung function decline and reservation. ${ }^{19-27)}$

\section{Type 2 diabetes}

Type 2 diabetes is a metabolic, chronic inflammatory disease. Diabetic inflammation results in local and systemic insulin resistance, which causes increases in circulating glucose levels. To compensate for increased insulin resistance, the functional $\beta$-cell mass first swells to induce hyperinsulinemia. Then, local and systemic inflammatory reactions destroy the resident islet $\beta$-cell mass. Blocking the inflammatory pathway can restore the insulin response. ${ }^{10)}$

The mechanism of action of AAT in type 2 diabetes is unclear, but AAT is known to protect pancreatic $\beta$-cells from apoptosis by inhibiting caspase- $3 .{ }^{28,29)}$ Recent studies have shown that the proportion of individuals with low AAT levels $(1.0 \mathrm{mg} / \mathrm{mL}$ or lower) was $50 \%$ higher among diabetic adult patients than the non-diabetic population. ${ }^{30)}$ The administration of AAT to patients with type 2 diabetes may reduce the severity of the disease.

\section{Type 1 diabetes}

Type 1 diabetes, known as juvenile diabetes or insulin- dependent diabetes, is a progressive condition caused by little or no insulin production by the pancreatic islet $\beta$-cells. ${ }^{31)}$ It can be caused by numerous factors, including genetics, infection, or the destruction of the pancreatic islet $\beta$-cells by autoreactive T cells. ${ }^{32)}$ The control of blood glucose levels and the reduction of diabetic complications are critically linked to the protection of pancreatic $\beta$-cells. Despite decades of advanced study, the ultimate treatment for this disease has not been determined.

However, recent studies on AAT have indicated that controlling inflammation and immune responses aids pancreatic $\beta$-cell function through the down-modulation of interleukin (IL)$1 \beta$ and other pro-inflammatory cytokines. ${ }^{33)} \mathrm{IL}-1 \beta$ is known to be harmful to insulin-producing cells. Although the levels of circulating AAT in type 1 diabetic patients may appear to be within normal ranges, AAT function is impaired as a result of extensive non-enzymatic glycation, suggesting that functional AAT levels may play a role in disease progression. ${ }^{34-36)}$ In the nonobese diabetic (NOD) mouse model, which is the autoimmune animal model for type 1 diabetes, serum AAT levels are only half those found in the majority of wild type mice. ${ }^{37)}$ NOD mice recover to normoglycemia 14 days after AAT treatment, and NOD mice that overexpress AAT have reduced insulitis and do not develop hyperglycemia. ${ }^{38)}$ In addition, the administration of clinical-grade human AAT to mice with chemically induced diabetes promotes pancreatic islet allograft survival and cytoprotective effects. ${ }^{29)}$

AAT therapy $(80 \mathrm{mg} / \mathrm{kg} / \mathrm{dose})$ was reported to be beneficial to $\beta$-cell function in adult type 1 diabetic patients. ${ }^{39)}$ Rachmiel et al. ${ }^{40)}$ reported that AAT treatment was feasible, without serious adverse complications, and improved glycemic control and serum peak c-peptide levels in pediatric patients with recently diagnosed autoimmune diabetes during a 37-week study period. Currently, 2 phase III, double-blind, randomized, placebocontrolled trials enrolling type 1 diabetic patients at the time of onset are underway, ${ }^{40)}$ and research into the function of AAT in diabetes is ongoing (Table 1).

\section{Chronic obstructive pulmonary disease}

COPD, the third leading cause of death in the world, can have a variety of causes, with cigarette exposure the most common. ${ }^{41)}$ The typical progression of COPD results in alveolar destruction, coughing/chronic mucus production, chronic inflammation, and irreversible airflow limitation characterized by protease imbalance and progressive loss of lung function. ${ }^{42)} \mathrm{COPD}$ treatments include inhaled bronchodilators, steroids, and longterm oxygen therapy. However, there are no effective therapies to reverse COPD.

Although AAT concentrations are within the normal range in COPD patients, their protease/antiprotease balances have been broken. ${ }^{43)}$ COPD airways present increased NE activity compared to that in healthy airways, resulting in exacerbation of mucus dehydration and reduction of mucociliary clearance. ${ }^{44)}$ AAT can minimize pulmonary damage through suppression 
Table 1. In vivo and in vitro biological activities of AAT on diabetes

\begin{tabular}{|c|c|c|}
\hline & Source and dose of AAT & Outcomes \\
\hline \multicolumn{3}{|l|}{ In vivo model } \\
\hline \multirow[t]{4}{*}{ Islet allograft immune response } & Aralast, 60 mg/kg; matrigel-embedded islets & $\begin{array}{l}\text { Graft survival prolonged, immune cell infiltration } \\
\text { reduced, intragraft insulin content increased, } \\
\text { intragraft VEGF transcript levels elevated }\end{array}$ \\
\hline & Aralast, $60 \mathrm{mg} / \mathrm{kg}$ & \\
\hline & Plasmid-derived hAAT, $450 \mu \mathrm{g} / \mathrm{mL}$ plasma levels & \\
\hline & $\begin{array}{l}\text { Grafts accepted, immune tolerance achieved, } \\
\text { Tregs localized at graft sites, systemic and local IL-1Ra } \\
\text { elevated }\end{array}$ & \\
\hline Islet autoimmune response & $\begin{array}{l}\text { Aralast, } 60 \mathrm{mg} / \mathrm{kg} \text {; adeno-associated delivery of } \\
\text { recombinant AAT }\end{array}$ & $\begin{array}{l}\text { Islet function preserved, immune tolerance achieved, } \\
\text { auto- and alloreactive grafts accepted }\end{array}$ \\
\hline Toxic $\beta$-cell injury & Aralast, $60 \mathrm{mg} / \mathrm{kg}$ & 48-Hour cell death reduced, insulin release preserved \\
\hline \multicolumn{3}{|l|}{ In vitro assay } \\
\hline \multicolumn{3}{|c|}{ Glucose-stimulated insulin secretion } \\
\hline Mouse islets & Aralast, $0.25-0.5 \mathrm{mg} / \mathrm{mL}$ & Cytokine-dampened insulin release restored \\
\hline Human islets & Aralast, $0.5 \mathrm{mg} / \mathrm{mL}$ & Impure islet culture insulin release improved \\
\hline$\beta$-cell lines & Prolastin, $0.125-1 \mathrm{mg} / \mathrm{mL}$ & Insulin release improved \\
\hline \multicolumn{3}{|l|}{$\beta$-cell-specific toxin (streptozotocin) } \\
\hline Murine MIN-6 cell line & Prolastin, $0.5 \mathrm{mg} / \mathrm{mL}$ & Apoptosis reduced \\
\hline
\end{tabular}

AAT, alpha-1 antitrypsin; VEGF, vascular endothelial growth factor; IL, interleukin.

Modified from Lewis. Mol Med 2012;18:957-70.10)

of NE activity. The theoretical, potential therapeutic effects of AAT therapy include the neutralization of serine proteinases from neutrophils, the reduction of leukotriene B4 released from macrophages and suppression of neutrophil chemotaxis. ${ }^{1)}$ One of the main disadvantages of the AAT therapy is that intravenous AAT arrives at the lung in a relatively inactive state. To overcome this obstacle, direct aerosol delivery to the airway has been introduced and short-term studies have shown improvements in protection of the lung epithelium and in lower respiratory anti-NE defenses. ${ }^{45)}$ To date, the inhaled AAT therapy has shown biochemical efficacy and safety in human studies. ${ }^{46)}$ In addition, the other recombinant AAT studies as stem cell therapy and gene therapy are underway. ${ }^{1)}$ However, a long-term follow-up study is needed for this methodology.

\section{Cystic fibrosis}

Cystic fibrosis (CF), caused by the mutation of CF transmembrane conductance regulator, progresses from childhood. CF patients have various pulmonary symptoms, such as the production of thick mucus, chronic airway infection, and inflammation, which lead to decreased pulmonary function and early death. ${ }^{47)}$ In a CF lung, neutrophil counts are elevated over those in a healthy lung and secreted NE leads to the destruction of the defense mechanisms of the lung against infection and inflammation. Thus, in CF, the treatment focus is on decreasing neutrophil hyperactivation and counteracting the effects of NE on the lung. To inhibit NE in the lung during CF progression, early studies have focused on the augmentation of systemic AAT levels by intravenous injection. ${ }^{48)}$ Recently, a randomized, double-blind, placebo-controlled phase 2a study in CF patients has been further performed to evaluate the safety of 100 or 200 $\mathrm{mg}$ of inhaled AAT once daily for 3 weeks in 30 adult subjects and reported that inhalation is safe and well tolerated. ${ }^{49)}$ Further multiple studies have demonstrated that AAT administered by inhalation can control neutrophil function and NE levels in a dose-dependent fashion as well as inflammation in the lung. ${ }^{48)}$ However, many obstacles still remain in applying AAT in CF since mixed results have been observed depending on the devices used as well as lung condition and NE concentration of patients.

\section{Others}

Graft-versus-host disease (GVHD), which remains a major problem in allogeneic hematopoietic cell transplantation, is ameliorated by the inhibition of IL-1 production/activity, inhibition of proteinase 3 -related IL-32 activation, and increased release of IL- 1 receptor antagonist and IL-10 in animal models. ${ }^{1)}$ In a human study, AAT was well-tolerated and demonstrated efficacy in the treatment of steroid-refractory severe acute GVHD ${ }^{50)}$ The injection of human AAT or the production of adenoviral plasmid-derived, circulating human AAT can delay rheumatoid arthritis development in a mouse model via the inhibition of IL-6, IL- $1 \beta$, and TNF- $\alpha$ along with the neutralization of serine proteinases and aggrecanase-1 from neutrophils. ${ }^{51)}$ Recently published preclinical and clinical reports have shown that AAT is related not only to infectious diseases, but also to inflammatory bowel disease, acute myocardial infarction, and connective tissue/rheumatoid diseases. ${ }^{10)}$ In addition, recent animal studies using the colitisassociated colon cancer mouse model demonstrated that AAT 
treatment resulted in a significant inhibition of tumor incidence accompanying amelioration of colonic inflammation compared with controls, strongly suggesting therapeutic potential of AAT in colitis-associated colon cancer (personal communication with Dr. Q. Cai).

\section{Conclusions}

The function of AAT was first illustrated by AAT deficiency and AAT has been used as a therapeutic agent for AAT deficiency. Recently, various functions of AAT have been confirmed in addition to its control of inflammation. This provides an opportunity to assess its potential therapeutic value for a variety of disease treatments in clinical and preclinical studies. There has also been active research into a more effective supply of AAT for diseases in which it is currently used as a therapeutic agent. In particular, recent and ongoing studies continue to investigate the association of AAT with and its potential for treating diabetes mellitus, especially type 1. The beneficial effects of AAT on insulitis, glycemic control, and pancreatic islet allografts have been confirmed in animal studies. AAT is also currently being used in clinical trials for diabetes. Based on these valuable findings on AAT, it may prove to be an alternative to various disease treatments and should be evaluated in further prospective human studies focused on long-term safety and efficacy.

\section{Conflict of interest}

No potential conflict of interest relevant to this article was reported.

\section{References}

1. de Serres F, Blanco I. Role of alpha-1 antitrypsin in human health and disease. J Intern Med 2014;276:311-35.

2. Alam S, Li Z, Janciauskiene S, Mahadeva R. Oxidation of Z al-antitrypsin by cigarette smoke induces polymerization: a novel mechanism of early-onset emphysema. Am J Respir Cell Mol Biol 2011;45:261-9.

3. Mahadeva R, Atkinson C, Li Z, Stewart S, Janciauskiene S, Kelley DG, et al. Polymers of Z alpha1-antitrypsin colocalize with neutrophils in emphysematous alveoli and are chemotactic in vivo. Am J Pathol 2005; 166:377-86.

4. Petrache I, Fijalkowska I, Medler TR, Skirball J, Cruz P, Zhen L, et al. alpha- 1 antitrypsin inhibits caspase- 3 activity, preventing lung endothelial cell apoptosis. Am J Pathol 2006; 169:1155-66.

5. Montanelli A, Mainardi E, Pini L, Corda L, Grassi V. Alpha1 -antitrypsin deficiency and nephropathy. Nephron 2002;90:114-5.

6. Kumar V, Abbas AK, Fausto N, Robbins SL, Cotran RS, editors. Robbins and Cotran pathological basis of disease. 7th ed. Philadelphia (PA): Elsevier/Saunders, 2005:911-2.
7. Stoller JK, Aboussouan LS. Alpha1-antitrypsin deficiency. Lancet 2005;365:2225-36.

8. Blank CA, Brantly M. Clinical features and molecular characteristics of alpha 1-antitrypsin deficiency. Ann Allergy 1994;72:105-20.

9. Yaghmaei M, Hashemi M, Shikhzadeh A, Mokhtari M, Niazi A, Ghavami S. Serum trypsin inhibitory capacity in normal pregnancy and gestational diabetes mellitus. Diabetes Res Clin Pract 2009;84:201-4.

10. Lewis EC. Expanding the clinical indications for $a(1)$ antitrypsin therapy. Mol Med 2012;18:957-70.

11. Lascano JE, Campos MA. The important role of primary care providers in the detection of alpha-1 antitrypsin deficiency. Postgrad Med 2017;129:889-95.

12. Needham M, Stockley RA. Alpha 1-antitrypsin deficiency. 3: Clinical manifestations and natural history. Thorax 2004;59:441-5.

13. Schmechel DE, Edwards CL. Fibromyalgia, mood disorders, and intense creative energy: A1AT polymorphisms are not always silent. Neurotoxicology 2012;33:1454-72.

14. Schmechel DE. Art, alpha-1-antitrypsin polymorphisms and intense creative energy: blessing or curse? Neurotoxicology 2007;28:899-914.

15. Ekeowa UI, Marciniak SJ, Lomas DA. a(1)-antitrypsin deficiency and inflammation. Expert Rev Clin Immunol 2011;7:243-52.

16. Campbell EJ. Alpha1-antitrypsin deficiency: incidence and detection program. Respir Med 2000;94 Suppl C:S18-21.

17. Luft FC. Alpha-1-antitrypsin and its relevance to human disease. J Mol Med (Berl) 1999;77:359-60.

18. Brantly ML, Wittes JT, Vogelmeier CF, Hubbard RC, Fells GA, Crystal RG. Use of a highly purified alpha 1-antitrypsin standard to establish ranges for the common normal and deficient alpha 1-antitrypsin phenotypes. Chest 1991;100:703-8.

19. Banauch GI, Brantly M, Izbicki G, Hall C, Shanske A, Chavko R, et al. Accelerated spirometric decline in New York City firefighters with $\alpha_{1}$-antitrypsin deficiency. Chest 2010;138:1116-24.

20. Seersholm N, Wencker M, Banik N, Viskum K, Dirksen A, Kok-Jensen A, et al. Does alphal-antitrypsin augmentation therapy slow the annual decline in FEV 1 in patients with severe hereditary alphal-antitrypsin deficiency? Wissenschaftliche Arbeitsgemeinschaft zur Therapie von Lungenerkrankungen (WATL) alpha1-AT study group. Eur Respir J 1997;10:2260-3.

21. Survival and FEV1 decline in individuals with severe deficiency of alpha1-antitrypsin. The Alpha-1-Antitrypsin Deficiency Registry Study Group. Am J Respir Crit Care Med 1998;158:49-59.

22. Wencker M, Fuhrmann B, Banik N, Konietzko N; Wissenschaftliche Arbeitsgemeinschaft zur Therapie von Lungenerkrankungen. Longitudinal follow-up of patients with alpha(1)-protease inhibitor deficiency before and during therapy with IV alpha(1)-protease inhibitor. Chest 2001;119:737-44. 
23. Tonelli AR, Rouhani F, Li N, Schreck P, Brantly ML. Alpha1 -antitrypsin augmentation therapy in deficient individuals enrolled in the Alpha-1 Foundation DNA and Tissue Bank. Int J Chron Obstruct Pulmon Dis 2009;4:443-52.

24. Dirksen A, Dijkman JH, Madsen F, Stoel B, Hutchison DC, Ulrik CS, et al. A randomized clinical trial of alpha(1)antitrypsin augmentation therapy. Am J Respir Crit Care Med 1999;160(5 Pt 1):1468-72.

25. Dirksen A, Piitulainen E, Parr DG, Deng C, Wencker M, Shaker SB, et al. Exploring the role of CT densitometry: a randomised study of augmentation therapy in alpha1antitrypsin deficiency. Eur Respir J 2009;33:1345-53.

26. Chapman KR, Stockley RA, Dawkins C, Wilkes MM, Navickis RJ. Augmentation therapy for alphal antitrypsin deficiency: a meta-analysis. COPD 2009;6:177-84.

27. Gøtzsche PC, Johansen HK. Intravenous alpha-1 antitrypsin augmentation therapy for treating patients with alpha-1 antitrypsin deficiency and lung disease. Cochrane Database Syst Rev 2010;(7):CD007851.

28. Petrache I, Fijalkowska I, Zhen L, Medler TR, Brown E, Cruz P, et al. A novel antiapoptotic role for alpha1antitrypsin in the prevention of pulmonary emphysema. Am J Respir Crit Care Med 2006;173:1222-8.

29. Zhang B, Lu Y, Campbell-Thompson M, Spencer T, Wasserfall C, Atkinson M, et al. Alphal-antitrypsin protects beta-cells from apoptosis. Diabetes 2007;56:1316-23.

30. Sandström CS, Ohlsson B, Melander O, Westin U, Mahadeva R, Janciauskiene $S$. An association between type 2 diabetes and alpha-antitrypsin deficiency. Diabet Med 2008;25:1370-3.

31. Eisenbarth GS. Type I diabetes mellitus. A chronic autoimmune disease. N Engl J Med 1986;314:1360-8.

32. Wang Y, Xiao Y, Zhong L, Ye D, Zhang J, Tu Y, et al. Increased neutrophil elastase and proteinase 3 and augmented NETosis are closely associated with $\beta$-cell autoimmunity in patients with type 1 diabetes. Diabetes 2014;63:4239-48.

33. Lewis EC, Mizrahi M, Toledano M, Defelice N, Wright JL, Churg A, et al. alpha1-Antitrypsin monotherapy induces immune tolerance during islet allograft transplantation in mice. Proc Natl Acad Sci U S A 2008;105:16236-41.

34. Ganrot PO, Gydell K, Ekelund H. Serum concentration of alpha-2-macroglobulin, haptoglobin and alpha-1antitrypsin in diabetes mellitus. Acta Endocrinol (Copenh) 1967;55:537-44.

35. Hashemi M, Naderi M, Rashidi H, Ghavami S. Impaired activity of serum alpha-1-antitrypsin in diabetes mellitus. Diabetes Res Clin Pract 2007;75:246-8.

36. Lisowska-Myjak B, Pachecka J, Kaczyńska B, Miszkurka G, Kadziela K. Serum protease inhibitor concentrations and total antitrypsin activity in diabetic and non-diabetic children during adolescence. Acta Diabetol 2006;43:88-92.

37. Lu Y, Tang M, Wasserfall C, Kou Z, Campbell-Thompson M, Gardemann T, et al. Alpha1-antitrypsin gene therapy modulates cellular immunity and efficiently prevents type
1 diabetes in nonobese diabetic mice. Hum Gene Ther 2006; 17:625-34.

38. Koulmanda M, Bhasin M, Hoffman L, Fan Z, Qipo A, Shi H, et al. Curative and beta cell regenerative effects of alphalantitrypsin treatment in autoimmune diabetic NOD mice. Proc Natl Acad Sci U S A 2008;105:16242-7.

39. Gottlieb PA, Alkanani AK, Michels AW, Lewis EC, Shapiro L, Dinarello CA, et al. al-Antitrypsin therapy downregulates toll-like receptor-induced IL- $1 \beta$ responses in monocytes and myeloid dendritic cells and may improve islet function in recently diagnosed patients with type 1 diabetes. J Clin Endocrinol Metab 2014;99:E1418-26.

40. Rachmiel M, Strauss P, Dror N, Benzaquen H, Horesh O, Tov N, et al. Alpha- 1 antitrypsin therapy is safe and well tolerated in children and adolescents with recent onset type 1 diabetes mellitus. Pediatr Diabetes 2016;17:351-9.

41. Chapman KR, Mannino DM, Soriano JB, Vermeire PA, Buist AS, Thun MJ, et al. Epidemiology and costs of chronic obstructive pulmonary disease. Eur Respir J 2006;27:188207.

42. Hogg JC, Timens W. The pathology of chronic obstructive pulmonary disease. Annu Rev Pathol 2009;4:435-59.

43. Fujita M, Nakanishi Y. The pathogenesis of COPD: lessons learned from in vivo animal models. Med Sci Monit 2007;13:RA19-24.

44. Low TB, Greene CM, O'Neill SJ, McElvaney NG. Quantification and evaluation of the role of antielastin autoantibodies in the emphysematous lung. Pulm Med 2011;2011:826160.

45. Hubbard RC, Brantly ML, Sellers SE, Mitchell ME, Crystal RG. Anti-neutrophil-elastase defenses of the lower respiratory tract in alpha 1-antitrypsin deficiency directly augmented with an aerosol of alpha 1-antitrypsin. Ann Intern Med 1989;111:206-12.

46. Griese M, Scheuch G. Delivery of Alpha-1 antitrypsin to airways. Ann Am Thorac Soc 2016;13 Suppl 4:S346-51.

47. Cantin AM, Hartl D, Konstan MW, Chmiel JF. Inflammation in cystic fibrosis lung disease: Pathogenesis and therapy. J Cyst Fibros 2015;14:419-30.

48. McElvaney NG. Alpha-1 antitrypsin therapy in cystic fibrosis and the lung disease associated with alpha-1 antitrypsin deficiency. Ann Am Thorac Soc 2016;13 Suppl 2:S191-6.

49. Gaggar A, Chen J, Chmiel JF, Dorkin HL, Flume PA, Griffin $\mathrm{R}$, et al. Inhaled alpha1-proteinase inhibitor therapy in patients with cystic fibrosis. J Cyst Fibros 2016;15:227-33.

50. Marcondes AM, Hockenbery D, Lesnikova M, Dinarello CA, Woolfrey A, Gernsheimer T, et al. Response of steroidrefractory acute GVHD to a 1-antitrypsin. Biol Blood Marrow Transplant 2016;22:1596-601.

51. Grimstein C, Choi YK, Wasserfall CH, Satoh M, Atkinson MA, Brantly ML, et al. Alpha-1 antitrypsin protein and gene therapies decrease autoimmunity and delay arthritis development in mouse model. J Transl Med 2011;9:21. 